\title{
Myotonia fluctuans
}

INSERM

\section{Source}

INSERM. (1999). Orphanet: an online rare disease and orphan drug data base. Myotonia fluctuans. ORPHA:99734

Myotonia fluctuans (MF) is a form of potassium-aggravated myotonia (PAM, see this term) which is cold insensitive, dramatically fluctuating and profoundly worsened by potassium ingestion. 